\title{
Spatiotemporal Simulation of Tourist Town Growth Based on the Cellular Automata Model: The Case of Sanpo Town in Hebei Province
}

\author{
Jun Yang, ${ }^{1,2}$ Peng Xie, ${ }^{1}$ Jianchao Xi, ${ }^{1}$ Quansheng Ge, ${ }^{1}$ Xueming Li, ${ }^{2}$ and Fanqiang Kong ${ }^{2}$ \\ ${ }^{1}$ Institute of Geographic Sciences and Natural Resources Research, CAS, Beijing 100101, China \\ ${ }^{2}$ Liaoning Key Laboratory of Physical Geography and Geomatics, Dalian 116029, China \\ Correspondence should be addressed to Peng Xie; xiepenggis@163.com
}

Received 31 January 2013; Accepted 26 March 2013

Academic Editor: Jianhong (Cecilia) Xia

Copyright (C) 2013 Jun Yang et al. This is an open access article distributed under the Creative Commons Attribution License, which permits unrestricted use, distribution, and reproduction in any medium, provided the original work is properly cited.

Spatiotemporal simulation of tourist town growth is important for research on land use/cover change under the influence of urbanization. Many scholars have shown great interest in the unique pattern of driving urban development with tourism development. Based on the cellular automata (CA) model, we simulated and predicted the spatiotemporal growth of Sanpo town in Hebei Province, using the tourism urbanization growth model. Results showed that (1) average annual growth rate of the entire region was $1.5 \mathrm{Ha}^{2}$ per year from 2005 to $2010,4 \mathrm{Ha}^{2}$ per year from 2010 to 2015, and $2.5 \mathrm{Ha}^{2}$ per year from 2015 to 2020 ; (2) urban growth rate increased yearly, with regional differences, and had a high degree of correlation with the Euclidean distance of town center, traffic route, attractions, and other factors; (3) Gougezhuang, an important village center in the west of the town, demonstrated traffic advantages and increased growth rate since 2010; (4) Magezhuang village has the largest population in the region, so economic advantages have driven the development of rural urbanization. It showed that CA had high reliability in simulating the spatiotemporal evolution of tourist town, which assists the study of spatiotemporal growth under urbanization and rational protection of tourism resources.

\section{Introduction}

Tourist towns have become increasingly important in tourism development and rural urbanization in recent years. Many researchers have focused on the practical use of tourism resources to achieve sustainable development of tourist towns $[1,2]$. Such studies have conducted qualitative analysis on the role of various factors in sustainable tourist town development, so it is difficult to objectively predict the future development of these towns. Therefore, it is important to effectively simulate the development trend of tourist towns and suggest reasonable development plans.

The cellular automata (CA) model was first introduced by John von Neumann in the 1940s under the inspiration of mathematician and physicist Stanislaw Ulam during the "Manhattan Project." The cellular automata (CA) model is a mathematical framework discrete in time, space, and state and is a dynamic evolution system consisting of a large number of interacting cells. Wolfram [3] played a significant role in promoting early CA studies and laid the theoretical basis for such work. Because the CA model has strong spatial computing power, a complex and global pattern can be formed through simple local operations. This model has been successfully applied to environmental change, landscape pattern replacement, forest fire diffusion, urban expansion, and other simulation studies [4-11].

In urban geography, CA has been applied in the simulation of large-scale urban changes to explore the application of discrete dynamic models in urban land use change $[12,13]$ and in the simulation of urban systems $[12,14,15]$. Zhou and Chen [16] studied CA and elaborated on its principles, potential problems, and research significance, while $\mathrm{Li}$ and Yeh [17] used binding CA in the simulation of sustainable urban development patterns. The above studies have played a large role in promoting the development and application of CA theory in China. 
In recent years, new developments in the urban CA model have been driven by progress in computer technology. Lauf et al. [18] studied an improved CA model, which included family and housing factors as the driving force through integrating system dynamics, to explore residential construction land expansion. García et al. [19] analyzed urban expansion in Northern Spain and Galicia by a variety of methods. Mitsova et al. [20] studied urban expansion and the protection of sensitive areas using CA based on landuse changes. Furthermore, a research has been conducted on the acquisition of CA conversion through combining neural network theory, data mining data and genetic algorithm theory, and on the enhanced simulation accuracy of the model [21-23].

The present paper applied the principle of CA to the simulation of tourist town urbanization, selected both suitable and limiting elements based on tourist town requirements for the development and protection of tourism resources, expanded the parameter system of traditional CA, and established the tourist town CA model to simulate Sanpo development from 2010 to 2020.

\section{Model and Methods}

2.1. Study Area. Sanpo town is located in the Taihang Mountain area, $28 \mathrm{~km}$ northwest of the Laishui County town of Baoding in Hebei Province, China. Sanpo is a national natural scenic area with significant regional advantages and is positioned $90 \mathrm{~km}$ east of Beijing, $170 \mathrm{~km}$ southeast of Tianjin and Langfang, and 90 and $190 \mathrm{~km}$ south of Baoding and Shijiazhuang, respectively. The town covers a total area of $200 \mathrm{~km}^{2}$, is 180 to $1500 \mathrm{~m}$ above sea level, and has a total population of 11,887 people. The Beijing-Yuanping Railway, Baoye Highway, and 108 Highway run through the town. Sanpo is the administrative heart of the Yesanpo National Scenic Area, covering most of the scenic area and having many residents. For management purposes, Sanpo consists of a number of smaller villages, such as Gougezhuang and Magezhuang (Figure 1). With the development of tourism in Yesanpo since 1986, Sanpo has gradually evolved into a specialized tourist town. The past 25 years of development provide clear temporal and spatial evidence on the evolution of tourism development in this representative rural tourism town in China.

2.2. Tourism CA Model Framework. Tourism urbanization is a complex process. To simulate the spatio-temporal evolution of a tourist town, the driving factors and comprehensive mechanisms of tourism urbanization evolution must be studied. We first analyzed the type of tourism in the study area, clarified the development of the main tourism industry chains, and collected land use data, topographic maps, remote sensing data, and economic and social statistics of Sanpo over the years. We further investigated the integration of data compilation and multisource data through the area, studied the spatio-temporal evolution and relationship between driving factors using GIS spatial analysis and statistic functions, and combined analytic hierarchy processes (AHP). On this basis, we conducted spatial growth simulation through Python language programming using CA and urbanization growth models with ArcGIS software, as shown in Figure 2.

2.3. Model Structure and Index System. The model was established based on raster data and using the GRID raster data coding format of ArcGIS. The cellular space of the model covered the entire study area with $10 \mathrm{~m} \times 10 \mathrm{~m}$ grids. To achieve multivariate data sharing, the model system used the WGS84 coordinate system. Cellular state space was divided into urban land, land that can be used for urbanization, and land that cannot be used for urbanization. Urban land information was provided by the land department of the Sanpo government, and land that cannot be used for urbanization was determined according to the requirements of protected areas and the constraining conditions of the terrain.

As external environment information of the cellular model, driving factor group data directly influences and controls the evolution of tourism urbanization. Tourism urbanization is a complex process with many influencing factors. By analyzing the comprehensive mechanisms of tourism and urbanization, we determined three major tourism urbanization factor groups and determined the weight coefficients of the driving factors by AHP (Table 1). The processing results of spatial data are shown in Figure 3. To achieve sustainable development and effectively protect tourism resources, natural reserves were taken as a spatial limiting factor, and the cell affected by spatial limiting factors could not be developed into a town.

2.4. Neighborhood Structure and Conversion Rules. The study area was a mountainous region with complex terrain. We considered two kinds of urbanization evolution power, specifically the influence of terrain and the influence of tourist factors. Firstly, the terrain on both sides of the valley watercourse was relatively flat with traffic arteries, so it was considered suitable for urban development. Secondly, the area was close to tourist attractions but beyond the safety distance of attraction protection to develop into a town.

2.4.1. Neighborhood Urbanization Function. The degree of urbanization was represented within the current cellular neighborhood, expressed by the proportion of urbanized cells within the scope of neighborhood, as follows:

$$
P_{(x, y)}=\frac{1}{N} \sum_{i=1, j=1}^{\Omega} X_{(i, j)},
$$

where $P_{(x, y)}$ represents the percentage of urbanized cells within the neighborhood space, $N$ represents the number of cells within the neighborhood space, $X_{(i, j)}$ represents urbanization cells, and $\Omega$ represents neighborhood space.

2.4.2. Cellular Conversion Probability. We determined the integrated value of the three major influencing factor groups 


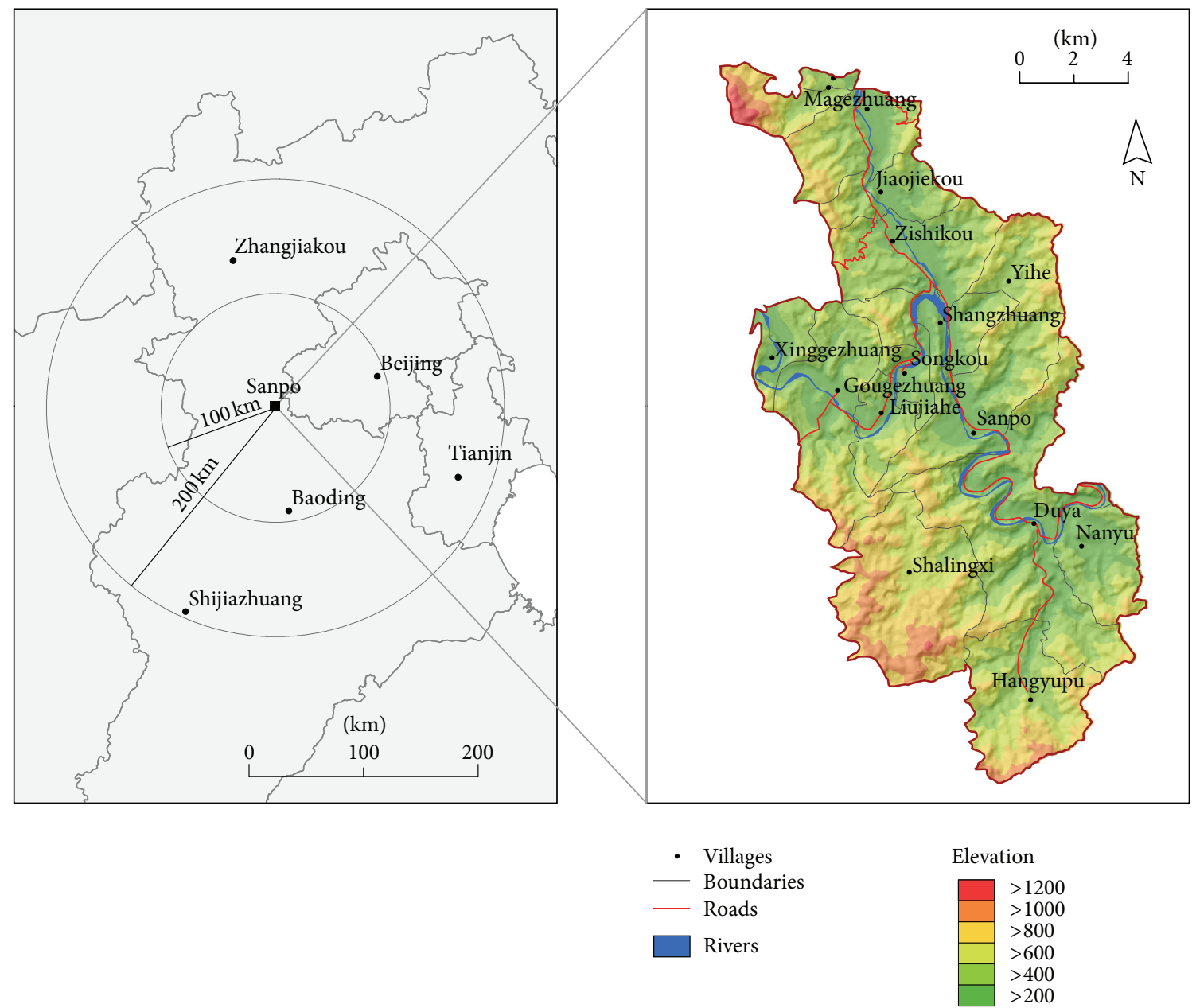

FIGURE 1: Location of study area.

and neighborhood urbanization function, representing the current cost value of cellular conversion, as follows:

$$
p_{i j}^{t}=\phi\left(r_{i j}^{t}\right)=\exp \left[\alpha\left(\frac{r_{i j}^{t}}{r_{\max }}-1\right)\right],
$$

where $\alpha$ represents the diffusion coefficient and $r_{\max }$ represents the highest property value. The simple expression of $r_{i j}^{t}$ is

$$
r_{i j}^{t}=\left(\sum_{k=1}^{m} F_{i j k}^{t} W_{k}\right) \prod_{k=m+1}^{n} F_{i j k}^{t}
$$

when $1 \leq k \leq m, r_{i j}^{t}$ represents the tourism urbanization driving factor, that is, the factors listed in Table 1; when $m<k$, $r_{i j}^{t}$ represents the spatial limiting factor, referring to natural reserves and rivers, the probability for it to develop into a town is 0 .

The simulation of CA was completed by multiple cycles. To express the uncertainty of tourism urbanization, $p_{i j}^{t}$ (probability of developing into urban land) and $p_{\text {threshold }}$ (pregiven threshold) were added in the cycle for comparison to determine whether the current cell can develop into a town, that is,

$$
\begin{cases}P_{i j}^{t} \geq P_{\text {threshold }} & \text { converted into urban land } \\ P_{i j}^{t}<P_{\text {threshold }} & \text { not converted into urban land. }\end{cases}
$$

\section{Results and Analysis}

Based on the above models and methods, we conducted dynamic simulation of cellular automata for the spatiotemporal growth of Sanpo. Figure 4(a) represents the actual construction land in 2005 and 2010, and Figure 4(b) represents the simulated construction land in 2010, 2015, and 2020.

Because the study area was located in remote mountains on the north and south sides of the middle reaches of a river, the simulation results showed that the overall urban scale growth trend still did not develop in the flat area around the town. Within the scope of the study period, the towns and villages did not develop into an urban landscape and remained independent and decentralized geographical units. 


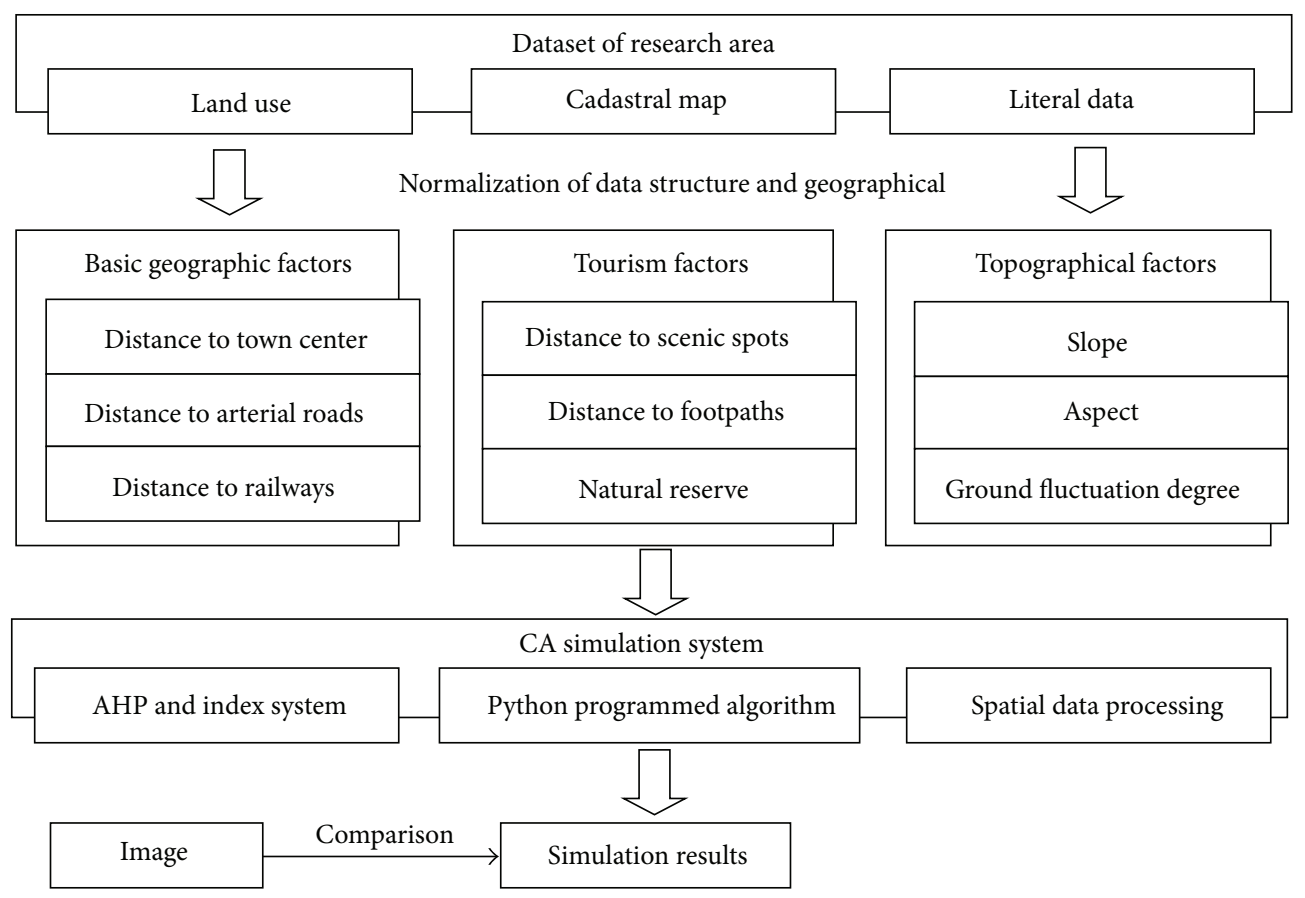

FIGURE 2: Frame diagram of spatio-temporal growth simulation of tourist town based on CA.

TABLE 1: Driving factors and weights of spatio-temporal growth of tourist town.

\begin{tabular}{|c|c|c|c|}
\hline Influencing factor & Variable type & Weight coefficient & Variable grading \\
\hline \multirow{3}{*}{ Basic geographic factors } & Distance to town center & 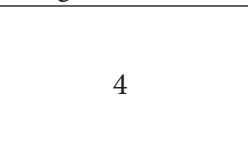 & $\begin{array}{c}\text { Grade 1: } 0 \sim 500 \mathrm{~m} \\
\text { Grade 2: 501 1000 m } \\
\text { Grade 3: } 1001 \sim 3000 \mathrm{~m} \\
\text { Grade 4: }>3000 \mathrm{~m}\end{array}$ \\
\hline & Distance to arterial roads & 4 & $\begin{array}{l}\text { Grade 1: } 0 \sim 100 \mathrm{~m} \\
\text { Grade 2: } 101 \sim 500 \mathrm{~m} \\
\text { Grade 3: } 501 \sim 1000 \mathrm{~m} \\
\text { Grade 4: }>1000 \mathrm{~m}\end{array}$ \\
\hline & Distance to railway & 2 & $\begin{array}{l}\text { Grade 1: } 0 \sim 100 \mathrm{~m} \\
\text { Grade 2: } 101 \sim 500 \mathrm{~m} \\
\text { Grade 3: 501 1000 m } \\
\text { Grade 4: }>1000 \mathrm{~m}\end{array}$ \\
\hline \multirow{2}{*}{$\begin{array}{l}\text { Geographic factors for } \\
\text { tourism }\end{array}$} & Distance to footpath & 3 & $\begin{array}{l}\text { Grade 1: } 0 \sim 100 \mathrm{~m} \\
\text { Grade 2: } 101 \sim 300 \mathrm{~m} \\
\text { Grade 3: } 301 \sim 600 \mathrm{~m} \\
\text { Grade 4: }>600 \mathrm{~m}\end{array}$ \\
\hline & Distance to scenic spots & 3 & $\begin{array}{l}\text { Grade 1: } 0 \sim 500 \mathrm{~m} \\
\text { Grade 2: 501 1000 m } \\
\text { Grade 3: } 1001 \sim 2000 \mathrm{~m} \\
\text { Grade 4: }>2000 \mathrm{~m}\end{array}$ \\
\hline \multirow{3}{*}{ Topographical factors } & Slope & 4 & $\begin{array}{c}\text { Grade } 1:<5 \text { degrees } \\
\text { Grade 2: } 6 \text { degrees } \sim 15 \text { degrees } \\
\text { Grade 3: } 16 \text { degrees } \sim 25 \text { degrees } \\
\text { Grade } 4:>25 \text { degrees }\end{array}$ \\
\hline & Aspect & 1 & $\begin{array}{l}\text { Grade } 1:-45 \text { degrees } \sim 45 \text { degrees } \\
\text { Grade 2: } 45 \text { degrees } \sim 135 \text { degrees } \\
\text { Grade 3: } 135 \text { degrees } \sim 225 \text { degrees } \\
\text { Grade 4: } 225 \text { degrees } \sim 315 \text { degrees }\end{array}$ \\
\hline & Ground fluctuation degree & 2 & $\begin{array}{l}\text { Grade } 1:<10 \\
\text { Grade } 2: 10 \sim 20 \\
\text { Grade 3: } 20 \sim 40 \\
\text { Grade } 4:>40\end{array}$ \\
\hline
\end{tabular}




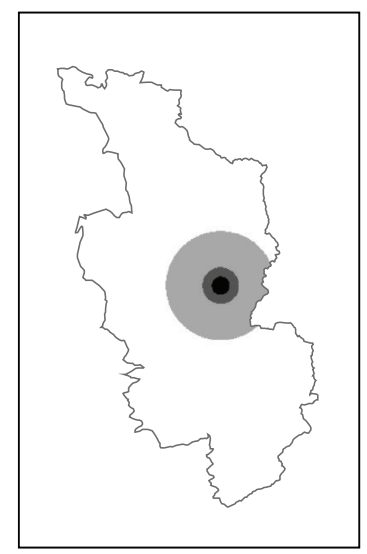

Distance to town center

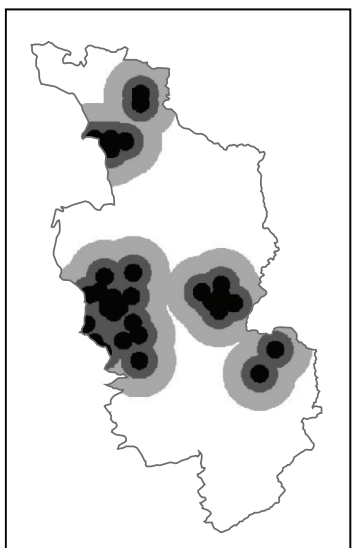

Distance to scenic spots

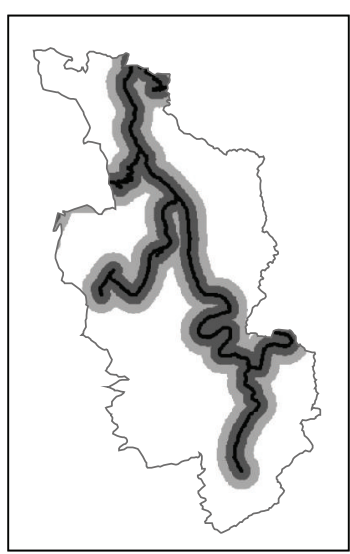

Distance to roads

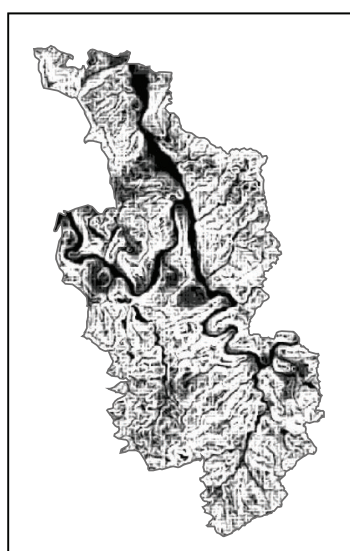

Slope

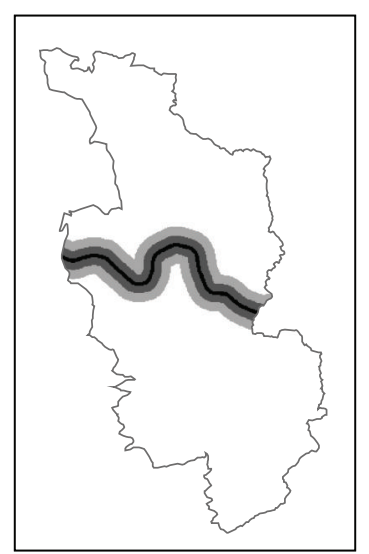

Distance to railway

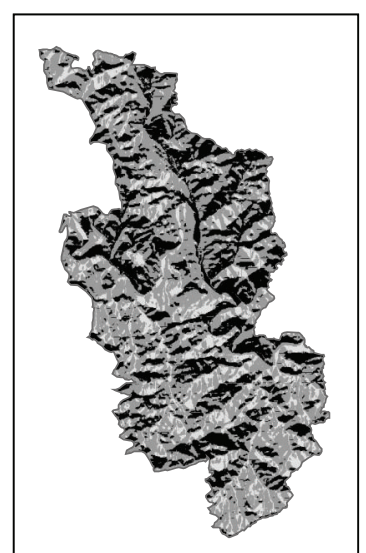

Aspect

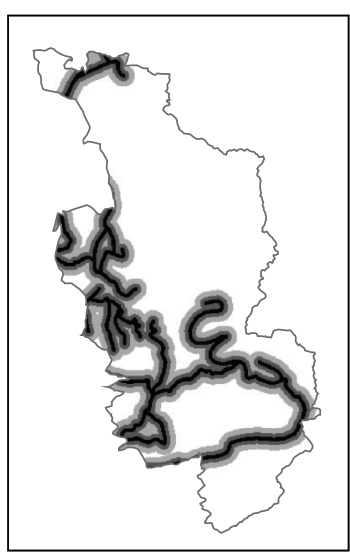

Distance to footpath

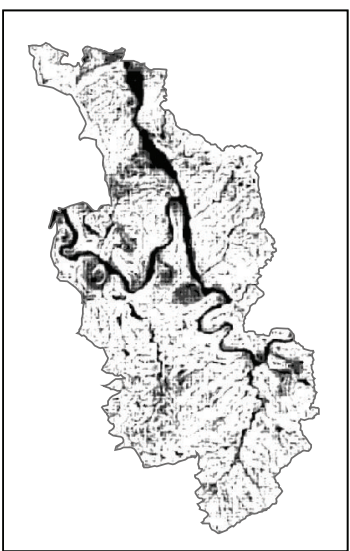

Ground fluctuation degree

FIGURE 3: Spatio-temporal growth driving factors of tourist town.

We further analyzed the characteristics of urban growth and its driving mechanism in the Sanpo area regarding changes in time and space patterns.

Differences in urban development speed in different time periods were observed. Urban land increased by $7.5 \mathrm{Ha}^{2}$ from 2005 to 2010, with an average increase of $1.5 \mathrm{Ha}^{2}$ per year, and was expected to increase by $20 \mathrm{Ha}^{2}$ from 2010 to 2015 , average increase rate of $4 \mathrm{Ha}^{2}$ per year, and by $17.520 \mathrm{Ha}^{2}$ from 2015 to 2020, average increase rate of $2.5 \mathrm{Ha}^{2}$ per year. These results were consistent with government development planning reports. Urban growth was mainly concentrated in the area near the town center, expanding at a rate of $1 \mathrm{Ha}^{2}$ per year, with the urban growth rate of other towns in the region being slow. This may be because the town center of Sanpo, which relies on the Yesanpo National Scenic Area, garnered significant support from development policies and funding in the early period of urban development. Furthermore, because urbanization adapts to the needs of local tourism development, tourism development accelerates urbanization in turn. Town urbanization accelerated after 2010 and was still the highest in the region with a growth rate of $1.3 \mathrm{Ha}^{2}$ per year. To the west of the town, Gougezhuang village developed rapidly, with an increase in construction land of $1.1 \mathrm{Ha}^{2}$ per year. Due to further demand for economic and tourism development in the Sanpo town center, contradictions existed in relation to sustainable development in the scenic area and land use restrictions, and other villages and towns (such as Gougezhuang and Magezhuang, Figure 4) showed tourism development potential with the support of resources and funding during this period. The simulated increase rate of urban land fell from 2015 to 2020, showing major growth near the town center because the growth area was topographically limited.

From the perspective of spatial patterns, urban growth regions in Sanpo were divided into three parts (right, Figure 4). The first was the northern area composed of South and North Chanfangzhuang and Magezhuang; the second was the western area, including Gougezhuang; and the third was Sanpo town center. Of these, the original urban town center covered the largest area and its growth rate was the fastest within the simulated period, demonstrating that the town center not only serves as a political, economical, and cultural center, but also as a tourist service base for the Yesanpo Scenic Area. The town center has developed at a fast rate due to the influx of people from surrounding towns and 

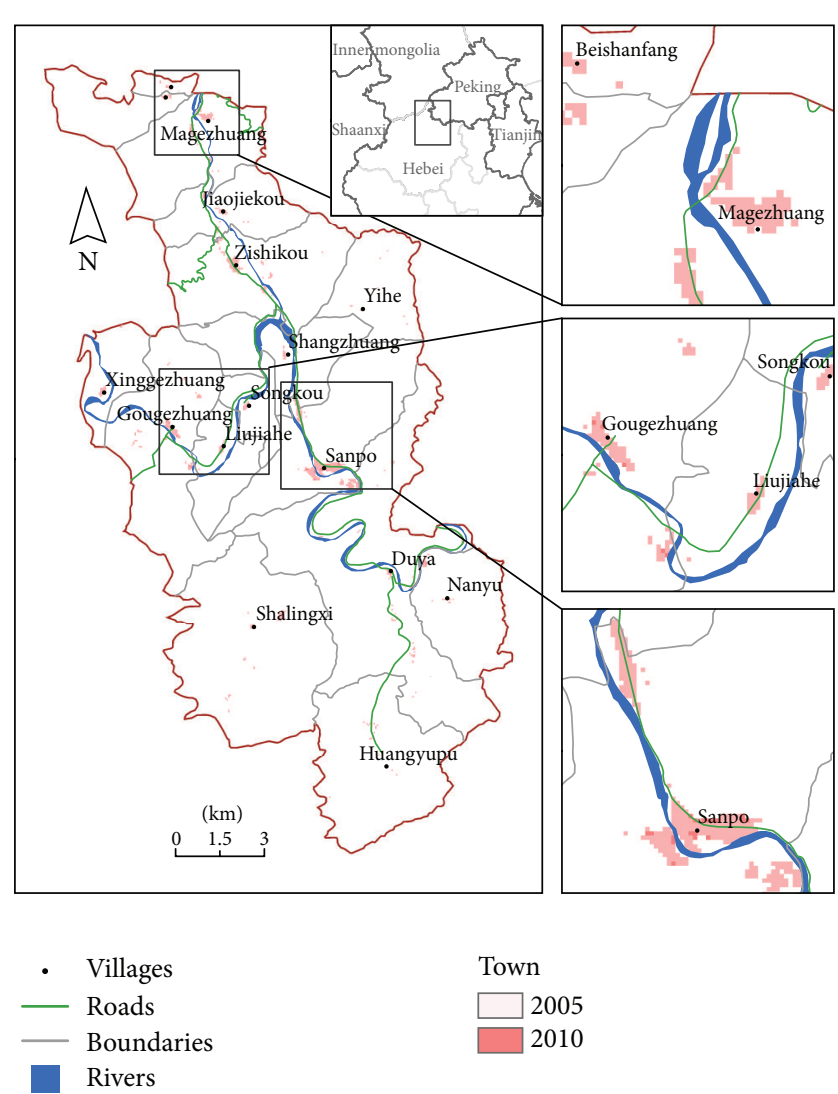
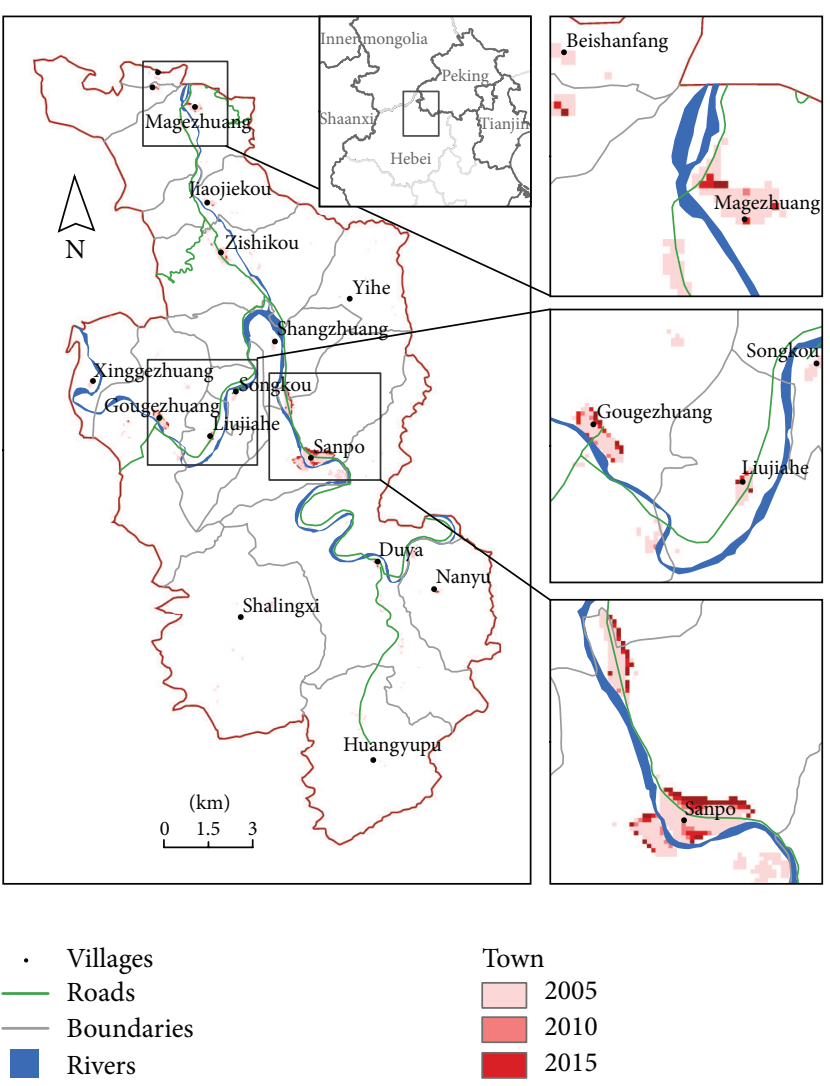

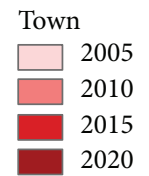

(b)

FiguRE 4: Spatio-temporal growth simulation results of Sanpo.

villages for employment, as well as the accommodation of temporary residents and visitors. Gougezhuang is an important central village to the west of the town, with an established Beijing-Yuanping Railway train station. Furthermore, it plays a role in radiating and driving the surrounding grass-roots villages, so there are unique advantages for tourism trade and service development in this village. In addition, with the largest population in this region, Magezhuang town growth will be inevitably achieved under the driving effect of the economy. For urban growth direction, most areas presented edge expansion; moreover, the urban growth rate of areas at the edge of town with traffic lines was faster than that of others, and the closer the area was to the tourist attraction, the faster its rate of urbanization was. The expansion of urban areas showed an obvious trend towards traffic and the tourism industry.

\section{Conclusions and Discussion}

This paper combined CA principles and GIS technology, established a tourism-type urban expansion model and simulated urban growth under the driving conditions of tourism factors using land use data of the Sanpo area from 2005 and 2010. The following was concluded.
(1) We analyzed the spatio-temporal growth of Sanpo using GIS technology and CA system principles, which reflected the role of tourism factors in regional urbanization and intuitively predicted the future trend of development of the town, with high reliability in solving spatio-temporal growth of the tourist city.

(2) By comprehensive analysis of the data and model, the Sanpo area was influenced by the natural environment, population growth, economic development, national policies, and other complex factors. The urban growth rate increased yearly, although with regional differences, and had a high degree of correlation with the Euclidean distance of town center, traffic route, attractions, and other factors.

(3) Because the Sanpo terrain was complex and tourism was a leading industry, the growth rates of towns surrounding the tourist attractions were relatively slow in the process of urban growth, achieving rational development, and utilization of tourism resources.

Because urbanization is a complex geographical process influenced by society, culture, and the economy, as well as by national economic policies and other factors, CA is still undergoing research and development and possesses a number of deficiencies [24]. Therefore, it is difficult to accurately simulate and predict urban growth. Some preliminary results have been made in researching the CA based model 
and simulating the growth process of tourist towns under microscale conditions; however, due to basic data limitations, the simulation accuracy of this study needs to be enhanced and the tourism urbanization CA simulation system requires further improvement.

\section{Acknowledgments}

The work described in this paper was substantially supported by the National Natural Science Foundation of China (nos. 40971299, 41171137) and Humanities Social Science Foundation of Ministry of Education (no. 09YJC790135).

\section{References}

[1] L. Lu and J. Ge, "Reflection on the research progress of tourism urbanization," Geographical Research, vol. 25, no. 4, pp. 741-750, 2006.

[2] Z. Wang and H. Yu, "Study on coupling development between development of tourism industry and small town construction in Zhangjiajie City," Economic Geography, no. 7, pp. 165-171, 2012.

[3] S. Wolfram, "Cellular automata as models of complexity," Nature, vol. 311, no. 5985, pp. 419-424, 1984.

[4] M. H. Afshar, M. Shahidi, M. Rohani, and M. Sargolzaei, "Application of cellular automata to sewer network optimization problems," Scientia Iranica, vol. 18, no. 3, pp. 304-312, 2011.

[5] Y. Feng and Z. Han, "Impact of neighbor configurations on spatially-explicit modeling results," Geographical Research, vol. 30, no. 6, pp. 1055-1065, 2011.

[6] S. Kokubo, J. Tanimoto, and A. Hagishima, "A new cellular automata model including a decelerating damping effect to reproduce Kerner's three-phase theory," Physica A, vol. 390, no. 4, pp. 561-568, 2011.

[7] E. A. Silva and K. C. Clarke, "Calibration of the SLEUTH urban growth model for Lisbon and Porto, Portugal," Computers, Environment and Urban Systems, vol. 26, no. 6, pp. 525-552, 2002.

[8] V. Spicer, A. A. Reid, J. Ginther, H. Seifi, and V. Dabbaghian, "Bars on blocks: a cellular automata model of crime and liquor licensed establishment density," Computers, Environment and Urban Systems, vol. 36, no. 5, pp. 412-422, 2012.

[9] F. Wu, "Calibration of stochastic cellular automata: the application to rural-urban land conversions," International Journal of Geographical Information Science, vol. 16, no. 8, pp. 795-818, 2002.

[10] H. Yu, Z. He, and X. Pan, "Wetlands shrink simulation using cellular automata: a case study in Sanjiang Plain, China," Procedia Environmental Sciences, vol. 2, pp. 225-233, 2010.

[11] H. Zhang, Y. Zeng, X. Jin, C. Yin, and B. Zou, "Urban land expansion model based on multi-agent system and application," Acta Geographica Sinica, vol. 63, no. 8, pp. 869-881, 2008.

[12] M. Batty, H. Couclelis, and M. Eichen, "Urban systems as cellular automata," Environment and Planning B, vol. 24, no. 2, pp. 159-164, 1997.

[13] H. Couclelis, "Cellular worlds: a framework for modeling micro-macro dynamics," Environment and Planning A, vol. 17, no. 5, pp. 585-596, 1985.

[14] M. Batty and Y. Xie, "From cells to cities," Environment and Planning B, vol. 21, supplement 21, pp. 531-548, 1994.
[15] M. Batty and Y. Xie, "Possible urban automata," Environment and Planning B, vol. 24, no. 2, pp. 175-192, 1997.

[16] Y. Zhou and Y. Chen, "Cellular automata and simulation of spatial complexity of urban systems: history, present situation and future," Economic Geography, vol. 20, no. 3, pp. 35-39, 2000.

[17] X. Li and A. G. O. Yeh, "Constrained cellular automata for modelling sustainable urban forms," Acta Geographica Sinica, vol. 54, no. 4, pp. 289-298, 1999.

[18] S. Lauf, D. Haase, P. Hostert, T. Lakes, and B. Kleinschmit, "Uncovering land-use dynamics driven by human decisionmaking: a combined model approach using cellular automata and system dynamics," Environmental Modelling \& Software, vol. 27-28, pp. 71-82, 2012.

[19] A. M. García, I. Santé, M. Boullón, and R. Crecente, "A comparative analysis of cellular automata models for simulation of small urban areas in Galicia, NW Spain," Computers, Environment and Urban Systems, vol. 36, no. 4, pp. 291-301, 2012.

[20] D. Mitsova, W. Shuster, and X. Wang, "A cellular automata model of land cover change to integrate urban growth with open space conservation," Landscape and Urban Planning, vol. 99, no. 2, pp. 141-153, 2011.

[21] X. Li, "Emergence of bottom-up models as a tool for landscape simulation and planning," Landscape and Urban Planning, vol. 100, no. 4, pp. 393-395, 2011.

[22] X. Li, Q. Yang, and X. Liu, "Discovering and evaluating urban signatures for simulating compact development using cellular automata," Landscape and Urban Planning, vol. 86, no. 2, pp. 177-186, 2008.

[23] X. Liu, X. Li, X. Shi, S. Wu, and T. Liu, "Simulating complex urban development using kernel-based non-linear cellular automata," Ecological Modelling, vol. 211, no. 1-2, pp. 169-181, 2008.

[24] P. M. Torrens and D. O'Sullivan, "Cellular automata and urban simulation: where do we go from here?" Environment and Planning B, vol. 28, no. 2, pp. 163-168, 2001. 


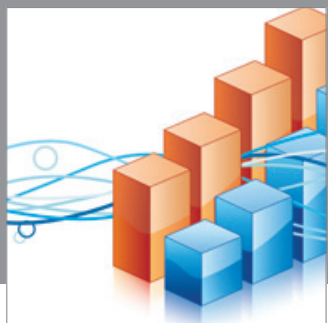

Advances in

Operations Research

mansans

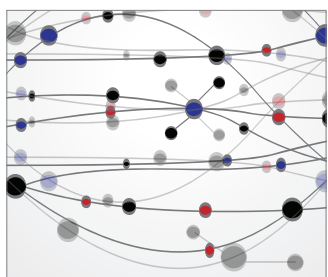

The Scientific World Journal
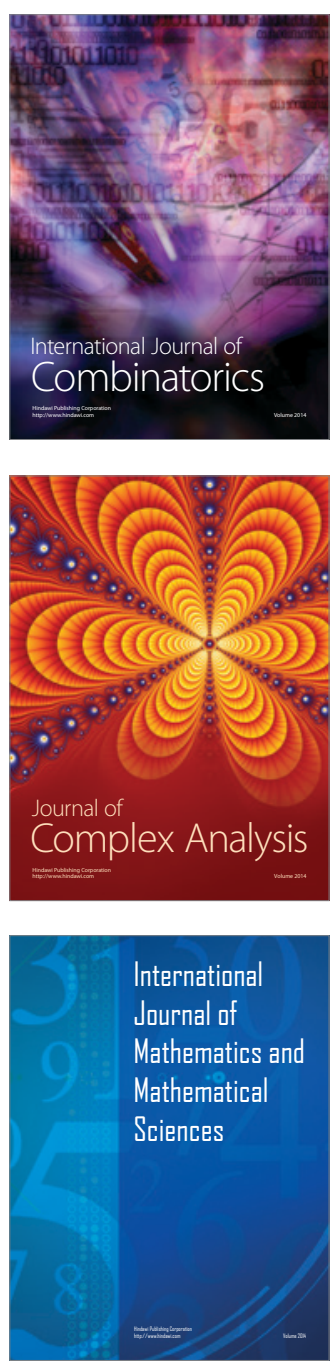
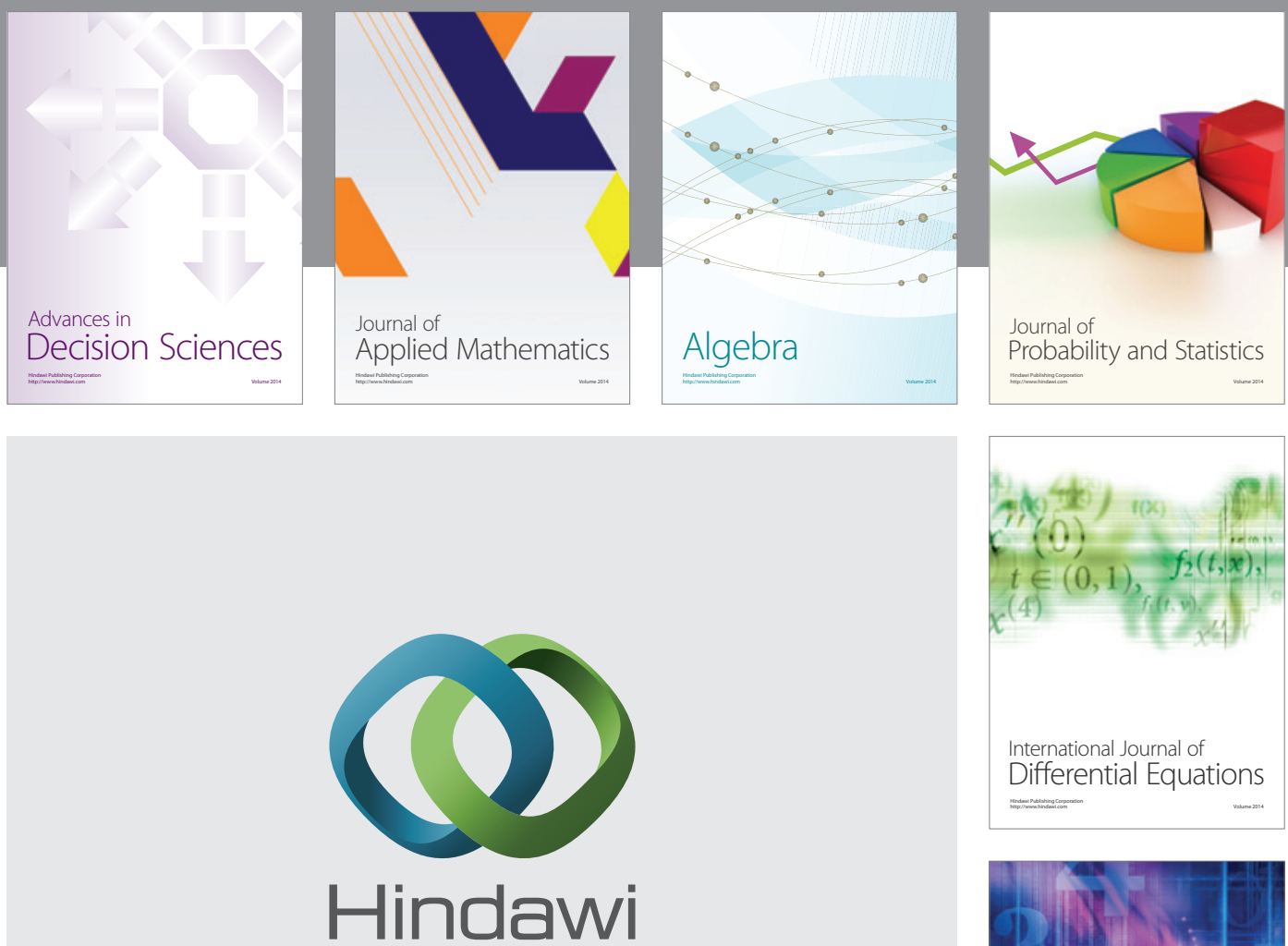

Submit your manuscripts at http://www.hindawi.com
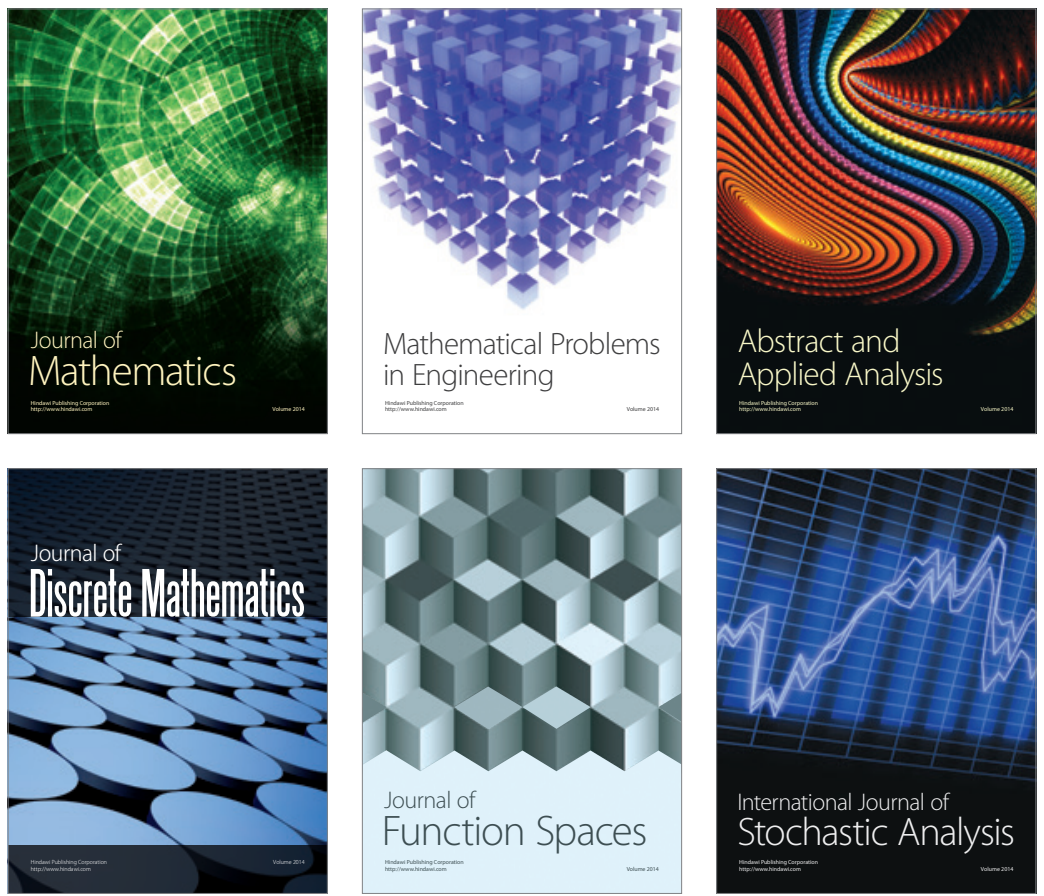

Journal of

Function Spaces

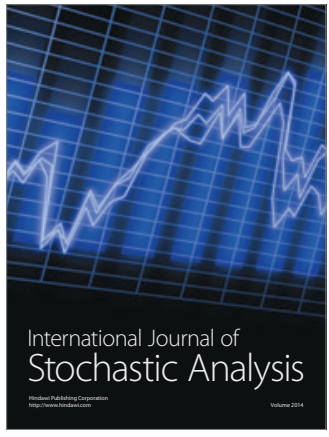

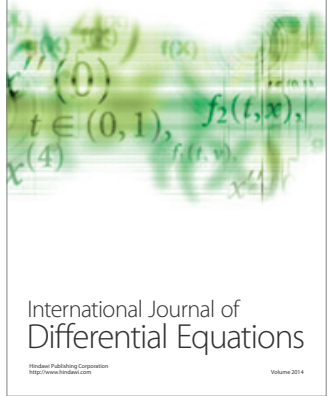
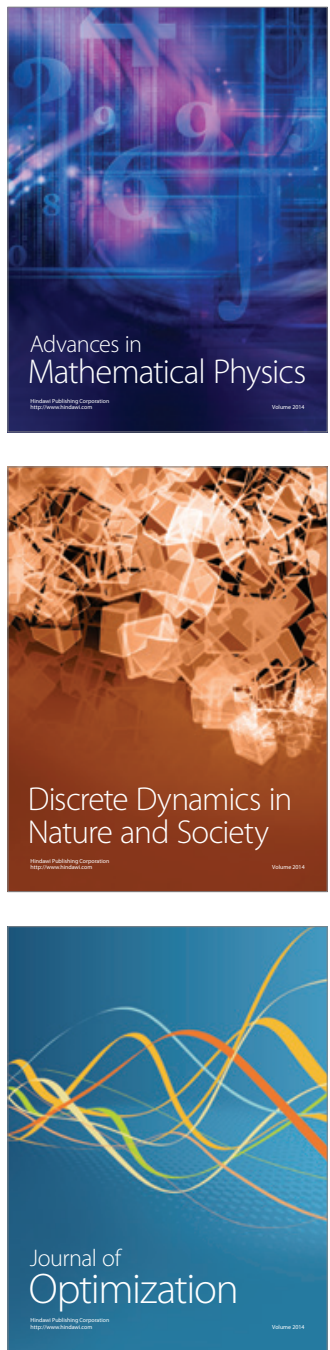